\title{
Potential limitations of biogenic silica as an indicator of abrupt climate change in Lake Baikal, Russia
}

\author{
George E. A. Swann ${ }^{*}$ and Anson W. Mackay
}

Environmental Change Research Centre, Department of Geography, University College London, 26 Bedford Way, London, WC1H OAP, UK

* Corresponding author g.swann@ucl.ac.uk

Keywords: Biogenic silica, Diatoms, Dissolution, Lake Baikal, Interstadials

\begin{abstract}
Biogenic Silica (BSi) has been one of the most important proxies for determining the palaeoclimate from Lake Baikal over glacial-interglacial cycles. Concentrations (calculated through a $1 \% \mathrm{Na}_{2} \mathrm{CO}_{3}$ wet-alkaline digestion) at a site in the north basin, however, reveal consistently low values during MIS 3 compared to greater than tenfold changes in diatom concentrations and biovolumes from c. 53.3-51.5 kyr BP. With similar glacial trends present at other low sedimentation sites, we suggest that significant amounts of BSi are removed from diatoms during glacials due to a relative increase in diatom dissolution at the sediment-water interface. This contrasts with existing results from other, higher sedimentation, sites such as those within the Selenga Delta which display a strong relationship between diatoms and BSi. Site selection is therefore essential when searching for Heinrich and other glacial millennial-scale events in Lake Baikal, and we recommend that both BSi and diatom concentrations be calculated together in future studies.
\end{abstract}

\section{Introduction}

An increasingly recognised feature in glacial lacustrine and marine sediments are the presence of abrupt climate events, such as Heinrich and/or smaller amplitude Dansgaard/Oeschger (D/O) events (Heinrich 1988; Dansgaard et al. 1993). While well studied in marine cores, uncertainty remains over the climatic response of these events in continental regions, particularly at sites far from oceanic influences. Obtaining reliable information from such sites is important since their reduced oceanic control permits associations to be made to hemispheric climatic processes and their global teleconnections. Additionally, these sites provide information concerning the rates of environmental change during these events in addition to their impact and regional leads and lags.

Lake Baikal, Russia, is one such location in a region of extreme continentality extending from $51^{\circ} 28^{\prime}-55^{\circ} 47^{\prime} \mathrm{N}$ to $103^{\circ} 43^{\prime}-109^{\circ} 58^{\prime} \mathrm{E}$ (Fig. 1) with an uninterrupted sedimentary sequence dating back to the Middle Eocene (Hutchinson et al. 1992) or Middle/Late Miocene (Williams et al. 2001). A significant 
limitation of conducting palaeoclimatic research in Lake Baikal is the lack of carbonates within the sedimentary record. As such, measurements of biogenic silica (BSi) have been extensively used to obtain palaeoclimatic information over glacial-interglacial cycles (e.g., Colman et al. 1995, 1999; Williams et al. 1997). With strong first-order linkages between BSi and orbital insolation, high BSi concentrations (c. 20-30 wt.\% as $\mathrm{SiO}_{2}$ ) indicative of high aquatic production are recorded during interglacials, while lower concentrations (c. 2-10 wt.\% as $\mathrm{SiO}_{2}$ ) prevail in glacials (Granina et al. 1993; Colman et al. 1995, 1999; Williams et al. 1997). Since diatoms in Lake Baikal constitute c. $98 \%$ of all sedimentary BSi (Granina et al. 1992), BSi profiles essentially represent a record of diatom palaeoproduction. BSi, though, is often a more practical measurement than diatom species analysis since it inherently accounts for diatom size and biovolume with significantly reduced analytical time.

As research in Lake Baikal shifts towards the detection of abrupt glacial climatic events, it becomes essential to understand the reliability of these BSi measurements, particularly in relation to the prevailing hydrological and sedimentary environments and the impact of diatom dissolution. Studies at the Buguldeika Saddle (Fig. 1), a hemipelagic site of moderate sedimentation in the south basin dominated by input from the Selenga River, have shown a strong relationship between BSi and diatom concentrations in MIS 3 leading to the detection of Heinrich events 5-2 (Colman et al. 1999; Prokopenko et al. 2001 a,b). Recent studies on diatom valve dissolution (e.g., Ryves et al. 2003; Battarbee et al. 2005; Straškrábová et al. 2005) warrant for further consideration, though, that increased diatom dissolution may have impacted the sedimentary and palaeoclimatic record in Lake Baikal during glacials. Here we investigate the relationship between BSi and diatom concentrations at a site of low sedimentation, Continent Ridge (Fig. 1), in a region unaffected by turbidites (Charlet et al. 2005). While Heinrich events have previously been detected at this site in Lake Baikal during MIS 3 using diatom concentrations (Swann et al. 2005), no assessment has yet been made on the reliability of BSi measurements in detecting abrupt glacial climatic events at these slow accumulating sites where the influence of turbidites is minimal.

\section{Methodology}

Samples from MIS 3/early MIS 2 were taken from a c. $3.9 \mathrm{~m}$ core (CON01-603-5) collected along an elevated ridge on the eastern side of the north basin of Lake Baikal (Latitude: 53²95'46"N Longitude: $108^{\circ} 91^{\prime} 37^{\prime \prime}$ ) (see Fig. 1), a site subsequently referred to as Continent Ridge. Continent Ridge represents a site of continuous sedimentation connected, but morphologically isolated, from the Academician Ridge (which has itself been analysed for BSi over the last 5 Ma BP (Williams et al. 1997)). Age models for core CON01-603-5 are based on palaeomagnetism and radiocarbon dating (see Swann et al. 2005). Core integrity has been confirmed by reflection seismic survey data and side scan sonar data (Charlet et al. 2005). BSi concentrations were measured on one hundred samples following the $1 \% \mathrm{Na}_{2} \mathrm{CO}_{3}$ wet-alkaline technique detailed in Conley and Schelske (2001). Samples were periodically shaken during the digestion with $1 \mathrm{ml}$ aliquots extracted after three, four and five hours and analysed for dissolved Si using a Perkin Elmer Optima 3300 ICP-AES. Samples were corrected for non-BSi through a least-squares linear regression (De Master 
$1979,1981)$

Slides for diatom analysis were prepared following methods outlined in Swann et al. (2005). A minimum of 100 diatom valves (or six transects) were counted per slide with diatoms being further assigned into three dissolution stages to create a Diatom Dissolution Index (DDI) (Flower and Likhoshway 1993). Although 300 valves is generally regarded as the optimum number needed for quantitative interpretations, the scarcity of preserved diatoms within the sedimentary record prevented this in all but a few samples. Similar problems have previously been experienced during periods of low production in Lake Baikal (e.g., Edlund and Stoermer 2000). Comparing diatom concentrations to BSi measurements can be problematic since diatom concentrations fail to consider variations in the size and mass of different taxa (Conley, 1988). Within Lake Baikal, the range of diatom taxa sizes are considerable. For example, the two common MIS 3 taxa of Cyclotella sp. cf. gracilis (Nikiteeva and Likhoshway) and Cyclotella baicalensis (Meyer) Skv. have approximate cell biovolumes of $340 \mu \mathrm{m}^{3}$ (calculated here) and $81500 \mu \mathrm{m}^{3}$ (Morley 2005) respectively. Diatom biovolumes, providing a more accurate indicator of expected changes in diatom BSi assuming diatom dissolution is minimal, were therefore calculated for the dominant planktonic and other large taxa using existing measurements from the Kazantsevo interglacial (approximately corresponding to MIS 5e) and the late glacial/Holocene sequences in Lake Baikal (Morley 2005; Rioual and Mackay 2005). Where required, biovolumes for other taxa were calculated following Hillebrand et al. (1999) and Rioual and Mackay (2005).

\section{Results}

Low BSi concentrations were observed in all samples from Continent Ridge following correction for non-BSi (range: $0.0-2.2$ wt.\% as $\mathrm{SiO}_{2}$ ) with fluctuations of c. 1.0-1.5 wt.\% as $\mathrm{SiO}_{2}$ throughout the $\mathrm{MIS} 3 / 2$ interval (Fig. 2). Sample reproducibility is $0.41 \mathrm{wt} \%$ as $\mathrm{SiO}_{2}$. Similar to the $\mathrm{BSi}$ record, diatom concentrations are also low throughout the sequence (c. $<1 \times 10^{7}$ valves/g dry wt) except from c. 53.3-51.5 kyr BP when concentrations increase from $0.056 \times 10^{7}$ valves/g dry wt. to $3.026 \times 10^{7}$ valves/g dry wt. (Fig. 2), reflecting a warm interval terminated by Heinrich event 5 (Swann et al. 2005). Diatom biovolumes exhibit similar trends to those in the diatom concentration record with values from c. 53.3-51.5 kyr BP also significantly higher at c. $11,000 \mu \mathrm{m}^{3} / \mathrm{g}$ dry wt. (Fig. 2). The DDI, however, indicates that over $99 \%$ of all valves preserved in the sediment are affected by dissolution (see Fig. 2 and images in Figs 3).

\section{Discussion}

A notable feature of the Continent Ridge record is the lack of an increase in BSi from c. $0.9-1.5$ wt. $\%$ as $\mathrm{SiO}_{2}$ during the interval from c. 53.3-51.5 $\mathrm{kyr}$ BP when diatom concentrations increase to $3.026 \times 10^{7}$ valves/g dry wt. and biovolume measurements rise to c. $11,000 \mu \mathrm{m}^{3} / \mathrm{g}$ dry wt. (Fig. 2). The absence of a BSi increase is significant since the diatom records suggests the sudden onset of warmer, interstadial, conditions from c. $53.3 \mathrm{kyr}$ BP with the decline in diatom concentrations at c. $51.5 \mathrm{kyr}$ BP associated with a period of climatic 
cooling and expansion of ice-cover/thickness, linked to the occurrence of Heinrich event 5 (see Swann et al. 2005). In contrasts, the BSi record does not display or indicate the presence of any of these these millennial-scale changes.

Re-analysis of the BSi and diatom profiles at the Academician Ridge reveals similar trends during MIS 3 (Williams et al. 1997; Khursevich et al. 2001) (see Fig. 4a). For example, notable increases in diatom concentrations approximately halfway through MIS 3 do not result in a corresponding rise in BSi (see Fig. 4a: arrow 1). Unlike Continent Ridge, a detailed chronology does not exist for the MIS 3 record at the Academician Ridge, preventing inter-site comparisons. However, this further evidence that BSi appears unable, in some instances, to detect the glacial millennial-scale events indicated by visual diatom analysis confirms that the results from Continent Ridge are not restricted to one site. That this situation exists is surprising given that BSi measurements have been fundamental in determining palaeoclimatic changes in Lake Baikal over glacial-interglacial cycles (Colman et al. 1995, 1999; Williams et al. 1997). Furthermore, laboratory experiments and interglacial sections of Lake Baikal cores have previously demonstrated a close relationship between BSi and diatom populations (Williams et al. 1997; Khursevich et al. 2001; Ryves et al. 2001; Karabanov et al. 2004). However, with almost all BSi originating from diatoms, these results from two different sites, each analysed by different groups working on Lake Baikal suggests a clear problem in applying BSi measurements to glacial aged sediments. It therefore becomes necessary to suggest possible mechanisms which may be operating to cause these features.

Important to the discussion is the record from the Buguldeika Saddle, a site in the south basin dominated by input from the Selenga River (Fig. 1). Unlike records from the Academician and Continent Ridge, a strong relationship between BSi and diatom concentrations exists at the Buguldeika Saddle during the last glacial (Fig. 4b) (Colman et al. 1999; Edlund and Stoermer 2000). Of particular relevance is the c. $10.0 \times 10^{7}$ valves/g increase in diatom concentrations which is synchronous with the peak in diatom concentrations at Continent Ridge from c. 53.3-51.5 kyr BP (Fig. 4b, arrow 2). However, while this interval is not marked in the BSi record at Continent Ridge, at the Buguldeika Saddle it is with BSi increasing from c. 11 wt.\% as $\mathrm{SiO}_{2}$ to c.20 wt.\% as $\mathrm{SiO}_{2}$ (Fig. 4b, arrow 2) (Colman et al. 1999; Edlund and Stoermer 2000).

The Academician Ridge, Continent Ridge and Buguldeika Saddle are all situated at similar water depths, 321-375 m, suggesting that sinking times to the sediment-water interface at all the sites are approximately constant. Sedimentation rates, though, are markedly higher during MIS 3 at the Buguldeika Saddle $(12.5 \mathrm{~cm} / \mathrm{kyr})$ compared to the Academician (c. $4.0 \mathrm{~cm} / \mathrm{kyr})$ and Continent Ridge $(5.7 \mathrm{~cm} / \mathrm{kyr})$ (Prokopenko et al. 2001a,b,c; Swann et al. 2005). Differences in sedimentation can not alone explain the differences in the BSi/diatom records during MIS 3 since sedimentation rates are relatively constant at individual sites over glacial-interglacial cycles and strong BSi/diatom relationships occur through Lake Baikal during interglacials (Williams et al. 1997; Colman et al 1999; Edlund and Stoermer 2000; Khursevich et al. 2001). 
Another possibility is that the dominant taxa at the Academician and Continent Ridge during the periods of high diatom production in MIS 3 are only weakly silicified. This would act to significantly reduce the amount of BSi within individual diatom frustules. At Continent Ridge samples from c. 53.3-51.5 kyr BP are dominated by $C$. sp. c.f. gracilis (63\% abundance), an extinct endemic species about whose ecology little is known. However, the simultaneous rise in diatom and BSi concentrations at the Buguldeika Saddle where a good BSi/diatom relationship exists (Fig. 4b, arrow 2) is almost entirely related to increases in C. gracilis with no other notable changes in individual diatom taxa concentrations (Edlund and Stoermer 2000). Consequently, we can be confident that $C$. gracilis is not weakly silicified. Similarly, the MIS 3 diatom sequence at the Academician Ridge are dominated by Aulacoseira baicalensis (Meyer) Simonsen and $C$. baicalensis, both of which are also known not to be weakly silicified (Battarbee et al. 2005).

A more likely explanation for the disconcordant BSi/diatom trends during MIS 3 may lies in the high degree of diatom dissolution in Lake Baikal. Dissolution is a predominant feature in Lake Baikal with only c. $1 \%$ of all living diatoms incorporated into the sedimentary record (Ryves et al. 2003). In interglacials, diatom dissolution is moderate. For example, over the last 1000 years c. $40-60 \%$ of sedimentary valves in Lake Baikal are affected by some form of dissolution (Mackay et al. 1998) while at Continent Ridge c. 60-90\% of valves are affected by dissolution in the Kazantsevo interglacial (DDI $=0.1-0.4$ ) which approximates to MIS 5e (Rioual and Mackay 2005). Conversely the MIS 3/2 Continent Ridge DDI record, which to date is the only quantitative dissolution record available for glacial sediment within the lake, suggests that dissolution is significantly higher with c. $99 \%$ of frustules subjected to some form of dissolution (DDI $=0-0.1$ ) and over $90 \%$ of all valves "heavily dissolved" (see Fig. 2, 3, and Swann et al. 2005).

Diatom dissolution today predominantly occurs at the sediment-water interface (Ryves et al. 2003). It is therefore likely that during glacials, dissolution also mainly occurred here. It also follows that at slower sedimentation sites the potential for diatom dissolution and/or grazing by benthic organisms is greater due to the increased duration spent by diatoms at the interface before burial. We argue that during glacials the increased duration spent by diatoms at the sediment-water interface became a critical factor at slow sedimentation sites such as Continent Ridge and Academician Ridge due to a relative increase in diatom dissolution which would have increased the removal of BSi from diatoms and the sedimentary record. This would have acted to prevent BSi measurements from accurately detecting real changes in sedimentary diatom concentrations, and explain why the BSi record is muted at both Continent Ridge, from c. 53.3-51.5 kyr BP (Fig. 2), and at the Academician Ridge (Fig. 4a: arrow 1). In contrast, the higher sedimentation rates at the Buguldeika Saddle during MIS 3 suggests that burial rates were sufficiently high there during the last glacial to prevent excessive diatom dissolution/BSi removal at the sediment-water interface resulting in a strong BSi/diatom relationship (Fig 4b).

Several mechanisms might lead to a higher relative diatom dissolution at slower accumulating sites 
such as Continent Ridge during glacials. Temperature is unlikely to play a major role as glacial bottom water temperatures are unlikely to alter significantly from interglacial levels. Instead we emphasise the role of biological processes on diatom dissolution. Recent work has highlighted the role of bacterial action in aiding dissolution by removing the protective layer of organic coating surrounding diatom frustules preparing the valve for chemical dissolution (Bidle and Azam 1999; Bidle et al. 2002; 2003). Within Lake Baikal, microbial activity has also been observed (Kuznetsov 1951; Kozhova and Kazantseva 1961), including the presence of saprophytic bacteria in the deepest waters (Straškrábová et al. 2005). Similarly other grazers, including zooplankton, also selectively remove diatom organic coatings leading to higher diatom dissolution (e.g., Cowie and Hedges 1996). The fully oxygenated water column of Lake Baikal permits many benthic faunal communities such as amphipods to survive at the sediment-water interface feeding on organic matter. Studies have also shown that modern faunal communities in Lake Baikal have prevailed through at least the Quaternary (Sherbakov 1999). Therefore, although populations may have been lower during glacial periods, rates of biological attack may have continued but perhaps at a higher relative intensity due to the lower numbers of diatoms in the water column. We suggest that during glacials, diatoms reaching the sediment-water interface are more intensively acted upon by biological communities, relative to interglacials, leading to the highly dissolved diatom frustules which characterise glacial sequences, such as at Continent Ridge. In agreement with Carter and Colman (1994), "diatom barren” glacial sequences in Lake Baikal may reflect lower production, combined with sustained and more intensive diatom dissolution, rather than an extinction or retreat of diatoms to shallow-water refugia as suggested by Karabanov et al. (2004).

\section{Conclusion}

BSi has been a fundamental proxy in eluding Lake Baikal's palaeoenvironment history over glacial-interglacial cycles. Results and re-analysis of existing data, though, indicates no relationship between $\mathrm{BSi}$ and diatom concentrations over glacial millennial-scale events at two slow sedimentation sites. We suggest this is most likely due to a relative increase in diatom dissolution at slower sedimentation sites during glacials, removing diatom BSi from the sedimentary record. This contrasts with results from the Buguldeika Saddle where sedimentation rates are significantly higher, suggesting that site selection and characteristics are important factors in determining whether BSi measurements will display glacial millennial-scale events. Despite the increased analytical time involved, such changes in Lake Baikal may instead be best identified using high magnification diatom concentration or biovolume light microscopy rather than BSi measurements. This is important given the need for further work in Lake Baikal to address glacial palaeoclimatic conditions and the teleconnections which appear to have prevailed between Europe and central Asia during these periods (see Prokopenko et al. 2001a,b; Swann et al. 2005).

\section{Acknowledgements}

This paper is submitted as part of the EU CONTINENT research project (http://continent.gfz-potsdam.de/) (Contract no. EVK2-2000-00057). The authors would like to thank Daniel Conley for providing the 
inter-laboratory sample material and Steve Colman, Nathalie Fagel, Patrick Rioual and an anonymous reviewer whose constructive comments and advice significantly improved the manuscript. BSi and diatom measurements were completed during a NERC MSc studentship to GEAS (NER/S/M/2002/11028) with additional NERC support (OSS/221/0503) for the use of the ICP-AES facility at Royal Holloway, University of London. Support for writing and analysing the data was provided by a NERC PhD studentship to GEAS (NER/S/A/2004/12193).

\section{References}

Battarbee R.W., Mackay A.W., Jewson D., Ryves D.B., and Sturm M. 2005. Differential dissolution of Lake Baikal diatoms: correction factors and implications for palaeoclimatic reconstruction. Global Planet. Change 46: 75-86.

Bidle K.D. and Azam F. 1999. Accelerated dissolution of diatom silica by natural marine bacterial assemblages. Nature 397: 508-512.

Bidle K.D., Manganelli M., and Azam F. 2002. Regulation of oceanic silicon and carbon preservation by temperature control on bacteria. Science 298: 1980-1984.

Bidle K.D., Brzezinski M.A., Long R.A., Jones J.L., and Azam F. 2003. Diminished efficiency in the oceanic silica pump caused by bacteria-mediated silica dissolution. Limnol. Oceanogr. 48: 1855-1868.

Carter S.J. and Colman S.M. 1994. Biogenic silica in Lake Baikal sediments: results from 1990-1992 American Cores. J. Great Lakes Res. 20: 751-760.

Charlet F., Fagel N., De Batist M., Hauregard F., Minnebo B., and Meischner D., and SONIC Team. 2005. Sedimentary dynamics on isolated highs in Lake Baikal: evidence from detailed high-resolution geophysical data and sediment cores. Global Planet. Change 46: 125-144.

Colman S.M., Peck J.A., Karabanov E.B., Carter S.J., Bradbury J.P., King J.W., and Williams D.F. 1995. Continental climate response to orbital forcing from biogenic silica records in Lake Baikal. Nature 378: 769-771.

Colman S.M., Peck J.A., Hatton J., Karabanov E.B., and King J.W. 1999. Biogenic silica records from the BDP-93 site and adjacent areas of the Selenga Delta, Lake Baikal, Siberia. J. Paleolimnol. 21: 9-17.

Conley D.J. 1988. Biogenic silica as an estimate of siliceous microfossil abundance in Great Lakes sediments. Biogeochemistry 6: 161-179. 
Conley D.J. and Schelske C.L. 2001. Biogenic Silica. In: Smol J.P., Birks H.J.B. and Last W.M. (eds), Tracking environmental change using lake sediments: Volume 3, Kluwer Academic Publishers, Dordrecht, pp. 281-293.

Cowie G.L. and Hedges J.I. 1996. Digestion and alteration of the biochemical constituents of a diatom (Thalassiosira weissflogii) ingested by an herbivorous zooplankton (Calanus pacificus). Limnol. Oceanogr. 41: 581-594.

DeMaster D.J. 1979. The marine budget of silica and ${ }^{32} \mathrm{Si}$. Ph.D Thesis, Yale University, 308 pp.

DeMaster D.J, 1981. The supply and accumulation of silica in the marine environment. Geochim. Cosmochim. Ac. 45: 1715-1732.

Edlund M.B. and Stoermer E.F. 2000. A 200,000-year, high-resolution record of diatom productivity and community makeup from Lake Baikal shows high correspondence to the marine oxygen isotope record of climate change. Limnol. Oceanogr. 45: 948-962.

Flower R.J. and Likhoshway Y.V. 1993. Diatom preservation in Lake Baikal. In: Grachev M.A. (ed.), Diatom algae as indicators of the changes of climate and environment: Fifth Workshop on Diatom Algae. Botanical Society Publications, Irkutsk, pp. 77-78.

Granina L.Z., Karabanov E.B., Shimaraeva M.K., Williams D.F., and Kuptsov V.M. 1992. Biogenic silica of Baikal bottom sediments used for palaeo reconstruction. In: International project on palaeolimnology and lake Cenozoic climate newsletter. 6: 53-59. Universitätsverlag Wagner, Innsbruck.

Granina L.Z., Grachev M.A., Karabanov E.B., Kuptsov V.M., Shimaraeva M.K., and Williams D.F. 1993. Accumulation of biogenic silica in bottom sediments of Baikal. Russian Geology and Geophysics 34: 126-135. (In Russian).

Hillebrand H., Dürselen, C-D., Kirschtel D., Pollingher U. and Zohary T. 1999. Biovolume calculations for pelagic and benthic microalgae. J. Phycol. 35: 403-424.

Hutchinson D.R., Golmshtok A.J., Zonenshain L.P., Moore T.C., Scholz C.A., and Klitford K.D. 1992. Depositional and tectonic framework of the rift basins of Lake Baikal from multichannel seismic data. Geology 21: 589-592.

Karabanov E.B., Williams D.F., Kuzmin M.I., Sideleva V., Khursevich G.K., Prokopenko A.A., Solotchina E., Tkachenko L., Fedenya S., Kerber E., Gvozdkov A., Khlustov O., Bezrukova E., Letunova P., and 
Krapivina S. 2004. Ecological collapse of Lake Baikal and Lake Hovsgol ecosystems during the Last Glacial and consequences for aquatic species diversity. Palaeogeogr. Palaeocl. Palaeoecol. 209: 227-243.

Khursevich G.K., Karabanov E.B., Prokopenko A.A., Williams D.F., Kuzmin M.I., Fedenya S.A., and Gvozdkov A.A. 2001. Insolation regime in Siberia as a major factor controlling diatom production in Lake Baikal during the past 800,000 years. Quatern. Int. 80-81: 47-58.

Kozhova O.M. and Kazantseva E.A., 1961. O sezonnykh izmeneniyakh chislennostyi bakterioplanktona v vodakh ozera Baikal. Mikrobiologiya 3: 113-117. (In Russian).

Kuznetsov S.I. 1951. Sravnitel'naya kharakteristika biomassy bakterii i fitoplanktona v poverkhnostnom sloe vody Sredniego Baikala. Trudy Baikalskoy Limnologicheskoy stancii 13: 217-224. (In Russian).

Mackay A.W., Flower R.J., Kuzmina A.E., Granina L.Z., Rose N.L., Appleby P.G., Boyle J.F., and Battarbee R.W. 1998. Diatom succession trends in recent sediments from Lake Baikal and their relation to atmospheric pollution and to climate change. Philos. T. Roy. Soc. B. 353: 1011-1055.

Morley D.W. 2005. Reconstructing past climatic change in continental Eurasia. Ph.D Thesis University College London, London, 388 pp.

Mortlock R.A. and Fröhlich P.N. 1989. A simple and reliable method for the rapid determination of biogenic opal in pelagic sediments. Deep-Sea Res. 36: 1415-1426.

Prokopenko A.A., Williams D.F., Karabanov E.B., and Khursevich G.K. 2001a. Continental response to Heinrich events and bond cycles in sedimentary record of Lake Baikal, Siberia. Global Planet. Change 28: 217-226.

Prokopenko A.A., Karabanov E.B., Williams D.F., Kuzmin M.I., Khursevich G.K., and Gvozdkov A.N. 2001b. The detailed record of climatic events during the past 75,000 BP from the Lake Baikal drill core BDP-93-2. Quatern. Int. 80-81: 59-68.

Prokopenko A.A., Karabanov E.B., Williams D.F., Kuzmin M.I., Shackleton N.J., Crowhurst S.J., Peck J.A., Gvozdkov A.N., and King. J.W. 2001c. Biogenic Silica Record of the Lake Baikal Response to Climatic Forcing during the Brunhes. Quat. Res. 55: 123-132.

Rioual P. and Mackay A.W. 2005. A diatom record of centennial resolution for the the Kazantsevo Interglacial stage in Lake Baikal (Siberia). Global Planet. Change 46: 199-219. 
Ryves D.B., Juggins S., Fritz S.C., and Battarbee R.W. 2001. Experimental diatom dissolution and the quantification of microfossil preservation in sediments. Palaeogeogr. Palaeocl. Palaeoecol. 172: 99-113.

Ryves D.B., Jewson D.H., Sturm M., Battarbee R.W., Flower R.J., Mackay A.W., and Granin N.G. 2003. Quantitative and qualitative relationships between planktonic diatom communities and diatom assemblages in sedimenting material and surface sediments in Lake Baikal, Siberia. Limnol. Oceanogr. 48: 1643-1661.

Sherbakov D.Yu. 1999. Molecular phylogenetic studies on the origin of biodiversity in Lake Baikal. Trends Ecol. Evol. 14: 92-95.

Straškrábová V., Izmest'eva L.R., Maksimova E.A., Fietz S., Nedoma1 J., Borovec J., Kobanova. G.I., Shchetinina E.V., and Pislegina E.V. 2005. Primary production and microbial activity in the euphotic zone of Lake Baikal (Southern Basin) during late winter. Global Planet. Change 46: 57-73.

Swann G.E.A., Mackay A.W., Leng M.J., and Demory F. 2005. Climatic changes in Central Asia during MIS 3/2: a case study using biological responses from Lake Baikal. Global Planet. Change 46: 235-253.

Williams D.F., Peck J.. Karabanov E.B.. Prokopenko A.A.. Kravchinsky V.. King J.. and Kuzmin M.I. 1997. Lake Baikal record of continental climate response to orbital insolation during the past 5 million years. Science 278: 1114-1117.

Williams D.F., Kuzmin M.I., Prokopenko A.A., Karabanov E.B., Khursevich G.K., Bezrukova E.V., 2001. The Lake Baikal drilling project in the context of a global lake drilling initiative. Quatern. Int. 80-81: $3-15$.

\section{List of figures}

Figure 1: Location of sampling site for Continent Ridge Kasten box core CON01-603-5 (Latitude: 5395'46"N Longitude: 108 91'37"W), Lake Baikal.

Figure 2: BSi measurements, diatom concentrations (Swann et al. 2005), diatom biovolumes and Diatom Dissolution Index (DDI) at Continent Ridge, Lake Baikal during MIS 3/2. No relationship exists between $\mathrm{BSi}$ and diatom concentrations/biovolumes from c. 53.3-51.5 kyr BP (shaded) suggesting that BSi is not recording the glacial millennial-scale changes reflected in the diatom record.

Figure 3: Typical, highly dissolved, diatoms from the MIS 3 sequence at Continent Ridge (A, B, C, D). Corresponding images (E, F, G, H) of the same taxa taken from the MIS 5e sections of the same core (Rioual and Mackay 2005) demonstrate the increased dissolution present in glacial aged sediments. A, B, E, F $=C$. 
gracilis; $\mathrm{C}, \mathrm{G}=$ Cyclotella ornata $(\mathrm{Skv}$.$) Flower; \mathrm{D}, \mathrm{H}=$ C. minuta.

Figure 4: A) BSi and diatom concentrations from the Academician Ridge during MIS 3 (Williams et al. 1997; Khursevich et al. 2001). As at Continent Ridge, BSi does not alter when diatom concentrations significantly increase (e.g., arrow 1). B) BSi and diatom concentrations from the Buguldeika Saddle during MIS 3 (Colman et al. 1999; Edlund and Stoermer 2000) in which a strong correlation exists between both proxies, particularly during the diatom rich phase (arrow 2) which corresponds to the increased diatom concentration at Continent Ridge from c. 53.3-51.5 kyr BP (for details on core correlation see Swann et al. (2005)). All figures adapted, revised and redrawn from Edlund and Stoermer (2000) and Khursevich et al. (2001). Different diatom concentration units for A and B reflect the different methodologies employed at each site. 

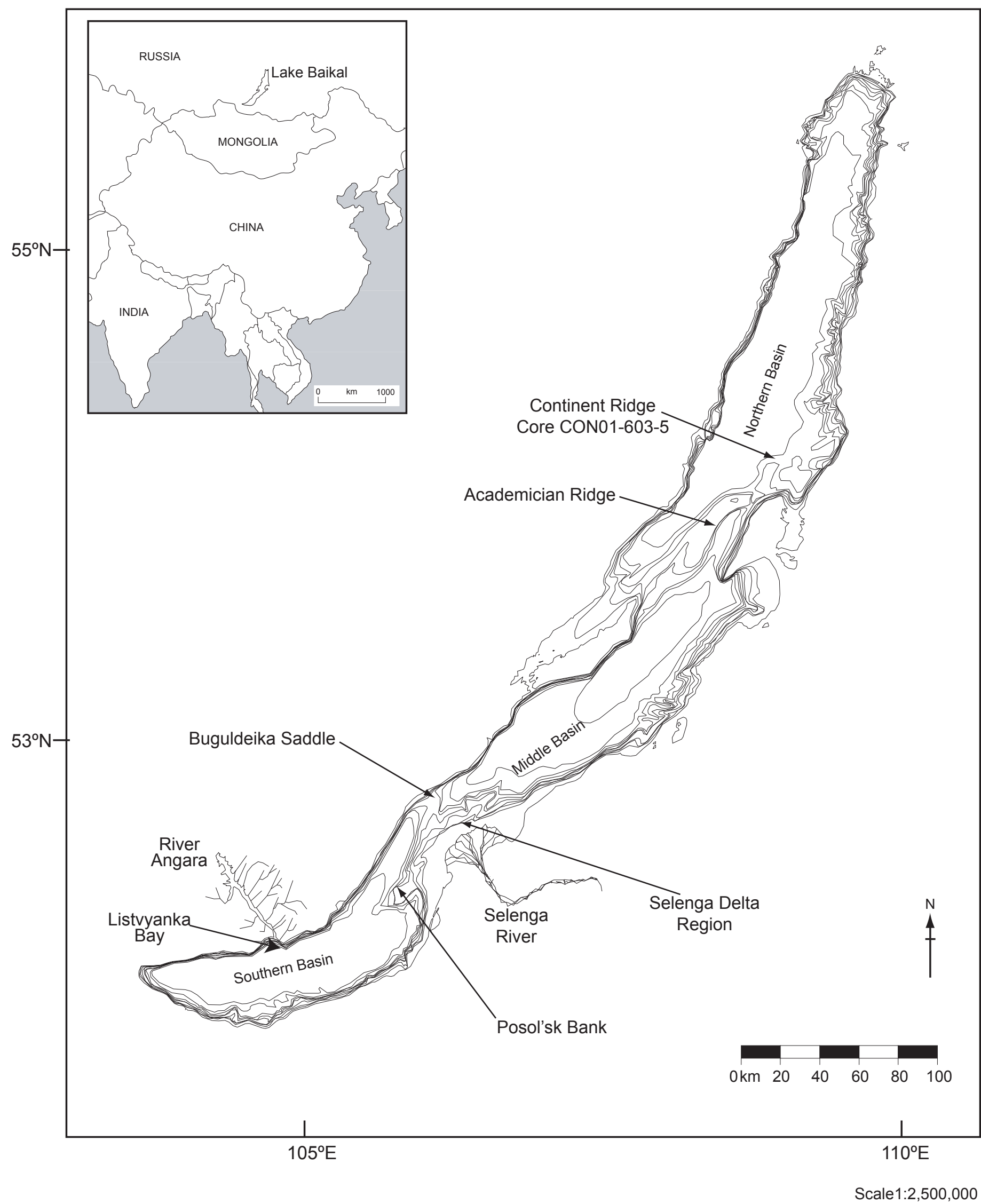

Figure 1 
Figure 2

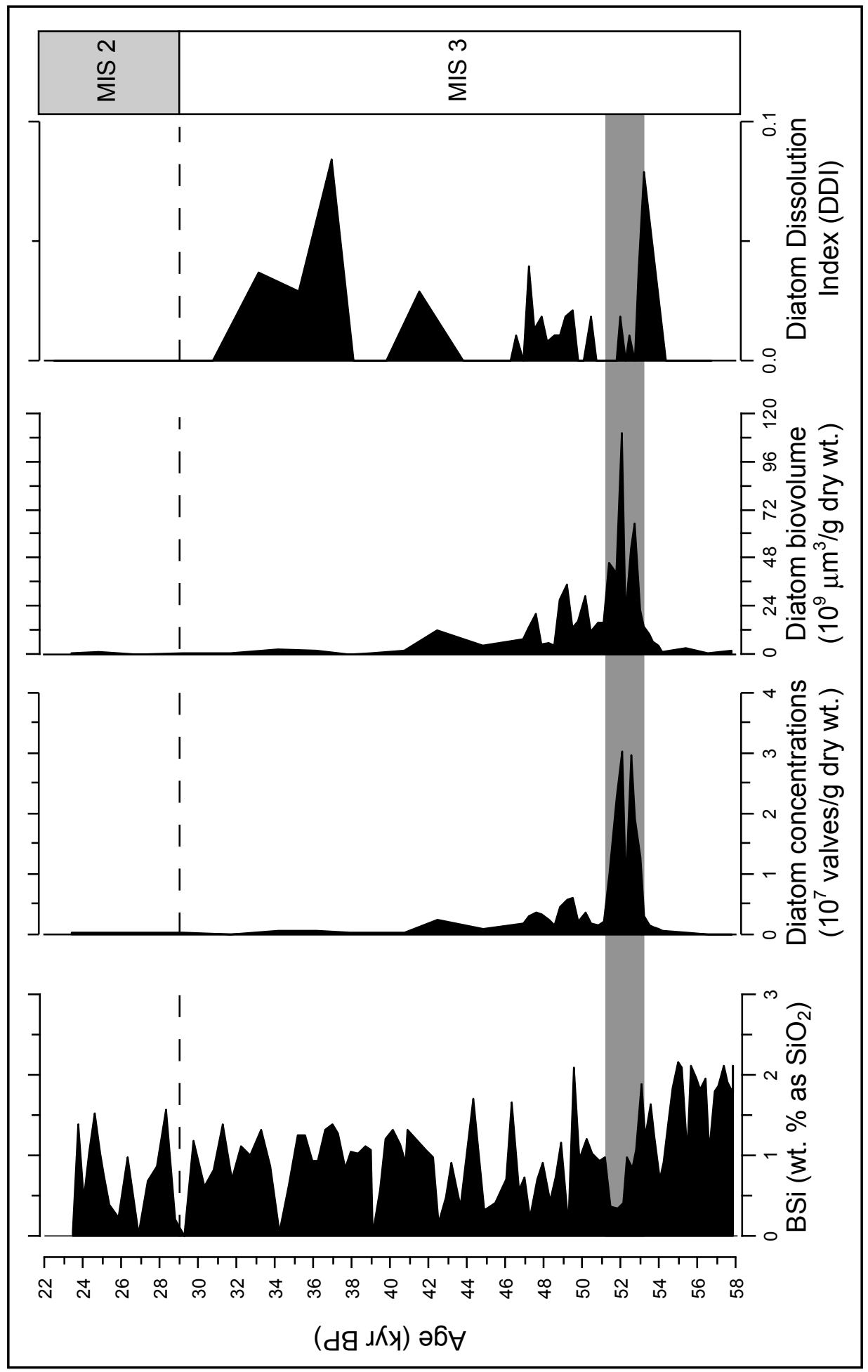


Figure 3

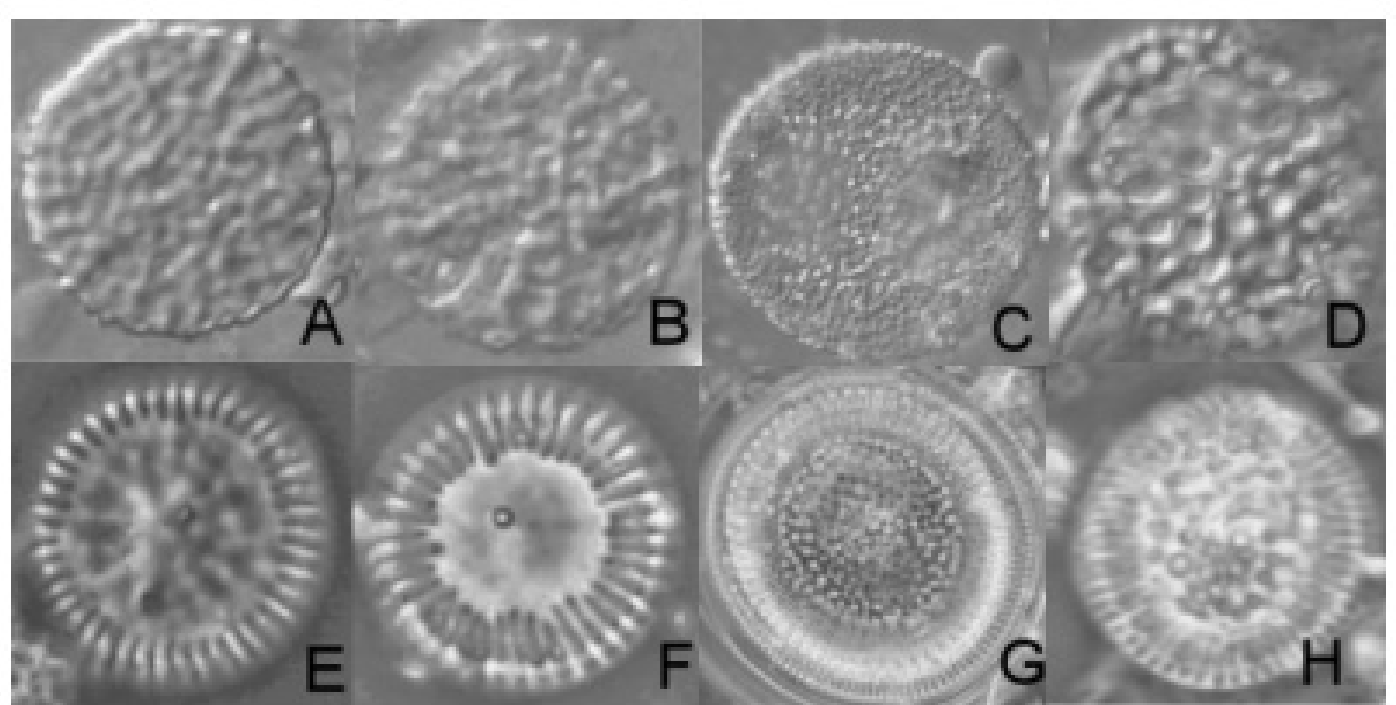


Figure 4

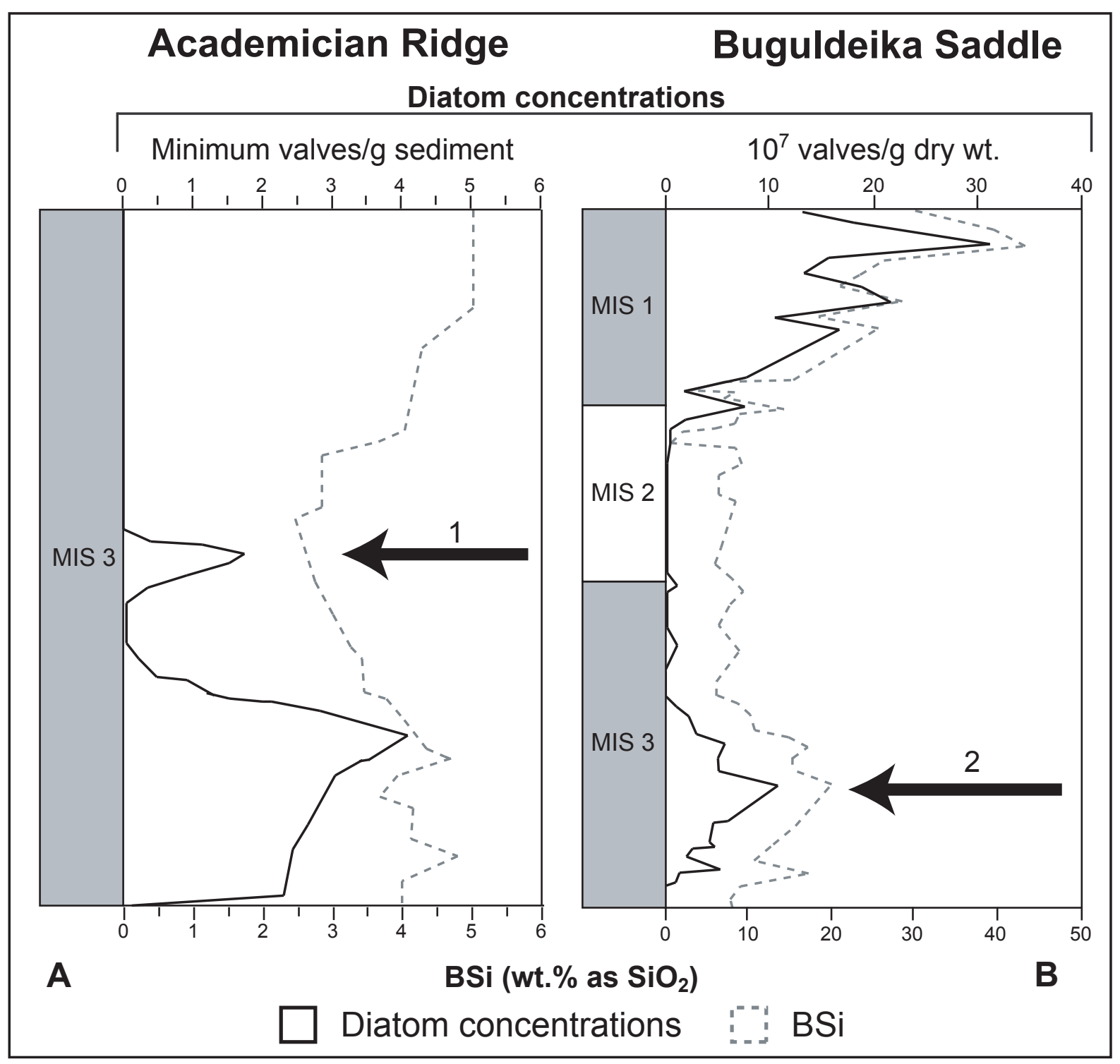

